\title{
Survey of recent literature on CGE trade models: with special reference to the case of Egypt
}

\author{
Amr Sadek Hosny \\ Department of Economics, University of Wisconsin-Milwaukee, Northwest Quadrant Building B, Room 4428, Milwaukee, WI 53201
}

Email address:

amrsadek@uwm.edu (A. S. Hosny)

\section{To cite this article:}

Amr Sadek Hosny. Survey of Recent Literature on CGE Trade Models: with Special Reference to the Case of Egypt, Journal of World Economic Research. Vol. 2, No. 1, 2013, pp. 9-19. doi: 10.11648/j.jwer.20130201.12

\begin{abstract}
This paper provides a recent summary of the literature on Computable General Equilibrium (CGE) trade models used to analyze the effects of trade policy changes. After a discussion of the advantages and limitations of CGE models, I address their typical structure and show how the model operates. Finally, I present a review of the impact of different trade liberalization scenarios in the case of a small open economy; Egypt.
\end{abstract}

Keywords: CGE, Trade Models, Egypt

\section{Introduction}

Economists often assert that trade liberalization improves economic welfare and helps alleviate poverty. But by how much? Computable General Equilibrium (CGE) models attempt to answer this question.

Kehoe and Kehoe (1994) argue that General Equilibrium models, like any economic model, are an abstraction of reality that is complex enough to capture the essential features of an economic situation, yet simple enough to be tractable. Specifically, Shoven and Whalley (1984, p.1008) argue that Applied General Equilibrium (AGE) models involve using a numerically specified general equilibrium model for policy evaluation. That's where the word applied comes in. A CGE model is an ex-ante applied general equilibrium model which numerically simulates the effects of a particular change that is introduced to the model (e.g. a change in trade policy).

This paper aims at providing an introduction to the literature review on CGE models used to analyze the effects of trade policy changes. Special reference is provided for the case of Egypt. Section two reviews the different methodologies that can be used to assess the impact of a change in trade policy. Section three looks into the advantages and limitations of using CGE models. Section four discusses the structure of a typical CGE model. Section five addresses how the model operates. Finally, section six reviews the CGE literature used to analyze different trade liberalization scenarios in the case of Egypt.

\section{Methodologies of Assessing the Im- pact of Trade Liberalization}

Before addressing the different models that can be used to assess the impacts of trade policies, one needs to ask why policy-makers need models in the first place. This is the topic of the following sub-section.

\subsection{Why do Policy-Makers Need Models?}

A legitimate question to ask is why do policy-makers need to concern themselves with trade models? The basic answer is that the use of models should help improve policy-making. More than two decades back, Dervis, de Melo and Robinson (1982) emphasized the support that modeling provides in the formulation and conduct of economic policy. More recently, Piermartini and Teh (2005, p.3) argued that economic models provide a theoretically consistent, rigorous and quantitative way of evaluating different trade policies. And specifically talking about CGE models, Hertel (1997) emphasized the value of a CGE framework to policy formulation and the flexibility that it provides policy-makers.

\subsection{Ex-Ante vs. Ex-Post Analysis}

One can identify at least two ways to analyze the effects of a trade policy change. The first is an ex-ante approach. This is basically a simulation of a change in trade policy, which involves projecting the future effects on a set of 
economic variables of interest. The ex-ante analysis approach is concerned with answering "what if" type of questions. An example is the use of CGE models to help policymakers understand the possible effects of a unilateral trade liberalization policy, or the potential effects on the economy of joining a free trade agreement.

The ex-post approach, on the other hand, uses historical data to conduct an analysis of the effects of a past trade policy. An example is gravity models, which try to attribute a cause to a certain effect, that is, for example, to show that trade agreements may affect bilateral trade flows.

\subsection{Partial vs. General Equilibrium Models}

Knowing the value added of understanding and applying models to address trade policy issues, the next step is to ask which type of model should be used. More accurately, there are a number of ways to assess the impact of trade policy on any given economy. The choice between these methods clearly depends on the objective of the research. If one merely aims at quantifying the impact of tariff reductions on government revenue for example, then a partial equilibrium approach may be used. On the other hand, if one wants to measure the consequences of a multilateral trade agreement on national incomes, trade, consumption and production, then a general equilibrium approach is more appropriate.

\subsubsection{Partial Equilibrium}

The main feature of a partial equilibrium model is that it does not have to consider equilibrium in all markets in order to study the impact on one market or sector. That's why partial equilibrium models usually focus only on one part or sector of the economy, assuming that the impact of that sector on the rest of the economy and vice versa is either non-existent or very small, thus ignoring interactions with other sectors. A partial equilibrium model also does not take into account the resource constraints of the economy; that to increase production in one sector resources need to be pulled away from other sectors.

A straight-forward example of a partial equilibrium analysis is the usual textbook example of the effect of an import tariff on the market of a certain commodity. Specifically, in the partial equilibrium analysis of the impact of introducing a tariff on a commodity, the focus will be on the market for the commodity, while all the cross-price effects in other markets are ignored as well as overall resource limitations and budget constraints.

This, however, should not imply that partial equilibrium models are not useful. It simply implies that a partial equilibrium model is most suited for policy analysis when the policy-maker is only interested in sectoral policies, or when the sector under study represents only a small share of total income, or policy changes are likely to change the price in only one market, while prices in other markets will remain constant. According to Bouet $(2008$, p11) the advantages of this type of models are its simplicity and tractability.

\subsubsection{General Equilibrium}

On the other hand, general equilibrium models can analyze how equilibrium is simultaneously determined in each and every market. According to Mas-Collel, Whinston, and Green $(1995$, p.511) a general equilibrium approach has the central feature of viewing the economy as a closed and interrelated system in which we must simultaneously determine the equilibrium values of all variables of interest. This stands in contrast to the partial equilibrium approach, where the impact on endogenous variables not directly related to the problem at hand is explicitly or implicitly disregarded.

Generally speaking, a general equilibrium analysis, according to Piermartini and Teh $(2005$, p.7), is able to account for all the linkages between sectors of an economy. These could be inter-linkages between industries, both backward and forward, or they could be linkages between household expenditures and incomes. A general equilibrium model imposes income/expenditure and resource constraints thus ensuring that households are on their budget lines and the total amount of primary factors employed in production does not exceed a country's factor endowments.

To cite an example, Bouet (2008, p.14) argues that the change in activity in a sector or a change in a price of a good may have economy-wide effects. This change in price may, for example, change demand for primary factors in a certain sector which changes the cost of production for other sectors as well as the demand of intermediate goods addressed to other sectors. Further, it may affect the level of net public receipts and/or expenses if the production or the utilization of some factors is either taxed or subsidized. All these effects are likely to affect the income level of households, which in turn change their levels of consumption, and so forth. These economy-wide effects can only be captured by a general equilibrium framework, while they are not accounted for in partial equilibrium models.

\subsubsection{The Case of Egypt}

In the case of Egypt, Helmy (2005) measures the impact of tariff reductions introduced by the Egyptian government in 2004 on government revenue using a partial equilibrium analysis. The study argued that the recent trade liberalization is likely to reduce government revenue in the short run, albeit modestly due to the expected increase in imports in response to lower prices. Specifically, Helmy (2005, p.16) concluded that tariff revenue will decrease by 0.6 percentage points of GDP assuming that demand for imports does not respond to the change in import prices, while revenue would decrease by 0.3 percentage points of GDP in the case that imports do respond to lower prices.

Other studies measure the impact of different trade liberalization scenarios on the Egyptian economy using a general equilibrium approach. Specifically, studies by Hoekman and Konan (2001) used a CGE model to analyze the Egypt-EU agreement, Konan (2003) analyzed Arab economic integration, Konan and Kim (2004) analyzed servic- 
es trade liberalization in Egypt and Tunisia, and Hoekman and Konan (2005) used a CGE analysis to study the possible impacts of an Egypt-USA free trade agreement. A detailed review of the literature of CGE models employed in the case of Egypt will be presented in section six of this paper.

\section{Advantages and Limitations of Using CGE Trade Models}

Many studies made use of the CGE approach to study the effects of trade policy changes on any given economy. Although the use of CGE's is widely accepted, thishowever-doesn't imply that the CGE type of analysis is not without limitations. This section of the paper will first provide a short history of the use of CGE trade models. Then it will look into the advantages and limitations of applying a general equilibrium framework to analyze the impact of trade policy using a CGE model.

\subsection{Brief History of CGE Trade Models}

We asserted that a CGE trade model is an ex-ante applied general equilibrium model which can numerically simulate the effects of a change in trade policy on any given economy. To begin with, quantitative or numerical models of the economy have actually been around for a long time. The earliest of these were input-output (IO) models of the economy introduced by Leontief (1941). Through these IO models, detailed descriptions of inter-industry linkages in an economy became available for the first time.

Walras expressed general equilibrium in mathematical terms as a system of simultaneous equations representing market equilibrium conditions, i.e., equality between supply and demand in each market in the economy. The second major advance was the approach adopted in the Arrow-Debreu model of general equilibrium (Arrow and Debreu 1954), where they specified the conditions to prove the existence of a competitive equilibrium. More importantly, they established a key link between market equilibrium and welfare. ${ }^{1}$

An important step leading to modern-day CGE models was the development of numerical methods for computing solutions to computable general equilibrium models. Piermartini and Teh (2005, p.10-11) argue that the first CGE model was probably that of Johansen (1960) which was a linear model that could be solved using linear algebra. Hansen and Scarf (1973) then developed numerical techniques for the computation of equilibrium prices in nonlinear models. Beginning in the 1980s, improvements in

\footnotetext{
${ }^{1}$ The First Welfare Theorem of Economics states that a competitive market equilibrium is Pareto-efficient. The Second Welfare Theorem states that any Pareto-efficient outcome can be achieved by a market equilibrium and a suitable reallocation of endowments. These results provided a firm theoretical foundation to the conjecture by Smith (1776) where he had famously suggested that an economy where each agent seeks only his own gain would end up promoting public welfare as if guided by an invisible hand.
}

computer software have made CGE modeling more accessible. Among today's more widely known and used CGE models of trade are the Global Trade Analysis Project (GTAP) developed by Hertel (1997), and the Michigan model of world production and trade developed by Deardorff and Stern (1986) which later came to be known as the Michigan Brown-Deardorff-Stern (BDS) model.

\subsection{Advantages of Using CGE Trade Models}

Ali El-Agraa (1989) listed a number of criteria to judge a model designed to analyze the impacts of trade liberalization policies. First, it should be carried out at an appropriate level of disaggregation, in both commodity and regional dimensions. Second, it should be capable of capturing the effects of trade on economic growth and economic welfare. And third, it should be general equilibrium in nature. CGE models fit those criteria quite well.

The most commonly cited advantage of the CGE approach is its theoretical consistency. Piermartini and Teh (2005, p.3) argue that since models are a distillation of economic theory, then their use will ensure that policymaking is guided by a correct theoretical understanding of how economies function. Borges (1986, p.15) actually argued that the most important strength of the general equilibrium methodology is its solid microeconomic foundation. CGE models explicitly specify the production and demand functions for all agents in the economy. It takes into account the interdependence among all markets and regions and provides numerical estimates of growth and distributional effects caused by changes in trade policy. Such a perspective clearly offers advantages compared to partial equilibrium models, which often miss important intermarket relationships and ignore macroeconomic impacts.

A second advantage is that CGE models impose accounting consistency. A CGE model usually builds on a closed accounting system which details all the basic identities for the modeled economy. Expenditures and income in these types of models have to match in that households cannot spend more than they earn. Therefore, any external shock (from FTA agreements for example) and the consequences of changes in domestic policy due to the implementation of the FTA rules can be quantitatively measured.

Another advantage is that CGE models can provide concrete measures of changes in welfare due to trade liberalization policies as compared to other methods. In addition, CGE can accurately measure not only the aggregate welfare changes, but also welfare consequences of changing trade policies in specific sectors. This is important because in reality, policy makers maybe concerned more about the impact of trade policy on individual sectors and special interest groups rather than the impact on the whole economy. This point is particularly important because it provides a framework for analyzing the tradeoff between efficiency and equity/distributional issues. Questions like who are the winners and losers from changing trade policies can be answered using the CGE framework, thus providing policy makers with a better understanding of the possible social 
results of the impacts of different trade policies. This point is shared by Kehoe and Kehoe (1994) who argue that CGE models are good tools for identifying winners and losers under a policy change, because they emphasize the impact of reallocating resources across different sectors of an economy.

Furthermore, CGE models are not confined to perfect competitive market economies. Recent applications, especially in developing countries, have moved away from the Walrasian ideal where the market clearing process is not a necessary requirement into incorporating imperfect competitive behavior, increasing returns to scale, and other structural elements and government intervention into the CGE framework.

In conclusion, CGE models have numerous advantages and are a powerful tool for analyzing the effects of trade policy changes. We end this section with the following statement by Bohringer, Rutherford, and Wiegard (2003, p.32): "CGE analysis constitutes a powerful scientific method for the comprehensive ex-ante simulation of adjustment effects induced by exogenous policy interference".

\subsection{Limitations of Using CGE Trade Models}

The first limitation of CGE models that once can think of relates to the fact that the comparative static approach used in CGE models (will be explained in more detail below) aims at examining how a change in trade policy may change the endogenous variables. An important thing to note, however, is that the concern is with discerning the difference between the initial and final equilibrium of the economy and not with the transition required to move from the initial equilibrium to the final one. The question that a CGE model provides an answer to is how much do prices, production, trade and welfare differ between the initial and final equilibrium of the economy? One limitation of this approach, according to Piermartini and Teh (2005, p.4), is that it may fail to capture some of the costs and benefits associated with the transition, and therefore it can overstate or understate the benefits from the change in trade policy. For example, for the benefits of trade liberalization to be realized, resources have to be moved from uncompetitive sectors to sectors where they can be more productively used. But this reallocation process may require workers to be retrained. Workers may also suffer temporary spells of unemployment during the transition. Capital that is specialized to the contracting sectors of the economy may not be transferable to the expanding sectors without expensive retooling. All the costs associated with this re-allocation of resources are not included in a comparative static analysis.

A second limitation concerns the point that CGE models do not answer the question of why do policy-makers are induced to undertake a certain trade policy? They only answer the question what if this trade policy is undertaken? For example, CGE models can do a good job in explaining the impact on a country from joining/forming some type of an economic integration agreement, but they can't explain the incentives the policy-makers have to joining/forming this agreement.

This distinction is often crucial since the effects are usually economic, whereas the incentives are usually political. Some studies, for example World Bank (2000, p.11) have argued that the purpose of integration is often political, and that the economic consequences - good or bad - are the side effects of the political decision. So this limitation of the CGE model simply asserts that the incentives that induce trade policy changes are not taken into account. For example, policy-makers may be induced to sign an FTA for political rather than economic reasons. They may do so with the intention to promote peace between the member countries. In fact, studies by the World Bank (2000, p.1216) and Schiff and Winters (2003, p.168-174) argued that many leading economic integration schemes were originally created to encourage intra-regional security. These studies cited the example of the EU, ECOWAS, MERCOSUR, and ASEAN economic groups. For further discussion about trade and peace, see Parlow (2009).

\section{Structure of a CGE Trade Model}

Looking at the general structure of CGE models in some detail will help us better understand why this framework is so flexible and can be applied beyond perfect competitive market economies.

A CGE model requires a complete specification of both the supply and demand sides of all markets, including all the nominal magnitudes in the circular flow. These numerical specifications imply that effects of any external economic shocks and consequences of any internal policy changes can be quantitatively measured. A CGE model should consist of the following components: A set of economic agents such as firms, households and government institutions, and a set of rules that these agents need to follow when they interact. The CGE model should also reflect trade both interregional and international. There also must be a set of explicit definitions of equilibrium conditions which are "system constraints" that must be satisfied for the whole economy but which are not taken into account by some (or all) agents in making their decisions.

Equilibrium can be defined as a set of signals or commands such that the resulting decisions of all agents jointly satisfy the system constraints. The signals or commands represent the equilibrating variables of the model. For example, in a perfect market economy, prices, wages, interest and exchange rate are the equilibrating variables that vary to achieve all market clearing.

\subsection{Circular Flow and Walrasian Equilibrium}

\subsubsection{Circular Flow}

The conceptual starting point for a CGE model is the circular flow of income in an economy, which is shown in Figure (1) in the Appendix. The main agents are households, firms, government and the international sector. 


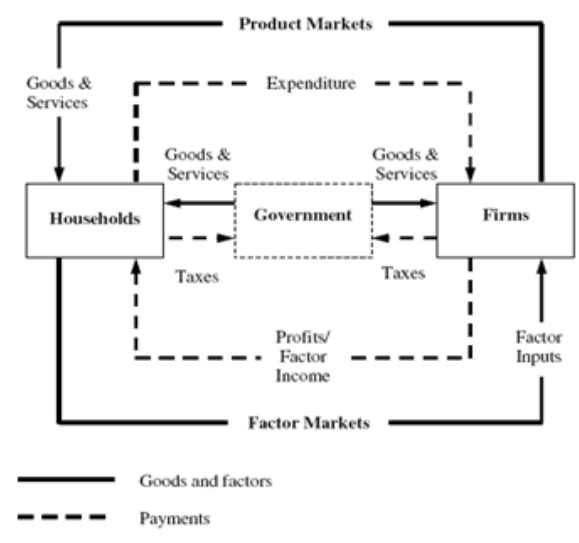

Figure 1. The Circular flow diagram.

Source: Wing (2004, p.29)

Households own the factors of production and are the final consumers of produced commodities. Consumption yields utility to households. With the objective of maximizing utility, households must decide on how much of its income to allocate to the goods and services that are available in the market. All of its endowments of land and capital are made available to firms (a full employment assumption) at the going market price for these factor services.

Firms rent the factors of production from the households to produce the goods and services that the households then consume. According to Piermartini and Teh (2005, p.12), the production side of a CGE model is represented by a set of goods (outputs), the inputs which are required to produce them and the technology of production. In most CGE models, the production technology is divided into two levels - an intermediate and a final level. In the intermediate level, goods are used as inputs to produce a composite intermediate good; primary factors (land, labor and capital) are also used to produce a new item called value added. The final level involves using both the value added and the composite intermediate good to produce the (final) output. The parameters that describe this technology are the fixed coefficients of the intermediate input stage and the elasticities of substitution.

Many CGE models also explicitly represent the government, but its role in the circular flow is often passive: to collect taxes and disburse these revenues to firms and households as subsidies and lump-sum transfers, subject to a budget balance.

The international sector, not shown in the figure, is a source of additional goods and services, i.e. imports to the domestic economy. This is matched by a payment flow from domestic residents to foreigners. Some of the G\&S produced in the domestic economy also go to the international sector as exports. This outward flow of G\&S is matched by an inward flow of payments to domestic producers. If no capital flows are allowed between the domestic economy and the rest of the world, the value of exports must equal the value of imports.

In tracing the circular flow one can start with the supply of factor inputs from households (e.g. labor and capital) to the firms and continue to the supply of goods and services from the firms to the households. Another way to look at the circular flow diagram is to begin with income which households receive for the services of labor and capital that they provide to firms. This income is then used as payments for the goods and services produced by the firms. The link between the domestic economy and the international sector is captured in the four sets of arrows that lead to and out of the international sector.

\subsubsection{Equilibrium}

Equilibrium in the economic flows as shown in Figure (1) results in the conservation of both product and value. These accounting rules are the cornerstones of Walrasian general equilibrium. On one hand, conservation of product, according to Wing (2004, p.4-5), by ensuring that the flows of goods and factors must be absorbed by the production and consumption activities in the economy, is an expression of the principle of no free disposability. It implies that firms' outputs are fully consumed by households, and that households' endowment of primary factors is in turn fully employed by firms. Thus, for a given commodity the quantity produced must equal the sum of the quantities of that are demanded by the other firms and households in the economy. Analogously, for a given factor the quantities demanded by firms must completely exhaust the aggregate supply endowed to the households. This is the familiar condition of market clearance.

On the other hand, conservation of value reflects the accounting principle of budgetary balance that for each activity in the economy the value of expenditures must be balanced by the value of incomes. Conservation of value implies that the sum total of revenue from the production of goods must be allocated either to households as receipts for primary factors rentals, to other industries as payments for intermediate inputs, or to the government as taxes. The value of a unit of each commodity in the economy must then equal the sum of the values of all the inputs used to produce it: the cost of the inputs of intermediate materials as well as the payments to the primary factors employed in its production. The principle of conservation of value thus simultaneously reflects constancy of returns to scale in production and perfectly competitive markets for produced commodities. These conditions imply that in equilibrium producers make zero profit.

These two conditions of market clearance and zero profit are employed by CGE models to simultaneously solve for the set of prices and the allocation of goods and factors that support general equilibrium. It is important to note, however, that Walrasian general equilibrium is defined not by the process of exchange by which this allocation comes about, but in terms of the allocation itself, which is made up of the components of the circular flow shown by solid lines in Figure (1). General equilibrium can therefore be modeled without the need to explicitly represent the compensating financial transfers. That's why Wing (2004, p.5) argues that 
CGE models typically do not explicitly represent money as a commodity. However, in order to account for such trades, the quantities of different commodities still need to be made comparable by denominating their values in some common unit of account. The flows are thus expressed in terms of the value of one commodity - the so-called numeraire good-whose price is taken as fixed. For this reason, CGE models only solve for relative prices.

\subsection{From Circular Flow to the Social Accounting Matrix}

The Social Accounting Matrix (SAM) builds on the circular flow conception of the economic system where every expenditure item must be matched by a corresponding receipt or income. According to Lofgren, Harris, and Robinson (2002, p.3) a SAM is a comprehensive, economy-wide data framework, typically representing the economy of a nation.

More technically, a SAM is a square matrix in which each account is represented by a row and a column. Each cell shows the payment from the account of its column to the account of its row. Thus, each sector of the economy will appear as a row (recipient of income) and as a column (as a source of expenditures) which means that the SAM is a square matrix. Given that income of a sector must equal its expenditure, the sum of the entries in the ith row must equal the sum of the entries in the ith column. This requirement is analogous to the accounting principle of conservation of value discussed above in the circular flow diagram.

According to Piermartini and Teh (2005, p.16-17), a SAM is constructed using several basic sources of economic information: the economy's input-output table, the national accounts, government budgetary accounts, balance of payments and trade statistics. The input output table provides information on the production sector of the economy, showing detailed inter-industry linkages and the contribution made by primary factors of production to each sector. Thus we know how much steel, rubber, plastics, etc. goes into the car industry. The macroeconomic accounts provide a breakdown of aggregate demand according to consumption, investment, government spending and the international sector (exports and imports). The trade account usually contains data on the destination and product composition of exports and imports. This means that the SAM shows not only how much steel, rubber, plastics, goes into the car industry but how much of each of those inputs are sourced domestically and how much sourced from abroad and from which trade partner. The government fiscal accounts provide information on public expenditures and revenues. Integrated with the other accounts in the $\mathrm{SAM}$, it is possible to obtain information on government spending on domestically produced goods and imports and to determine how much revenues are generated from taxes applied to international trade (tariffs).

\subsection{Equations in the CGE Model}

According to Lofgren, Harris, and Robinson (2002, p.8) a standard CGE model explains all of the payments recorded in the SAM. The model therefore follows the SAM disaggregation of factors, activities, commodities, and institutions. It is written as a set of simultaneous equations, many of which are nonlinear. The equations define the behavior of the different agents. For production and consumption decisions, behavior is captured by nonlinear, first-order optimality conditions. In simple words, firms are driven by profit maximization, while consumers are driven by utility maximization. The CGE model is square, meaning that the number of equations is equal to the number of variables. This is a necessary condition for the existence of a unique solution.

\subsection{Trade and the Armington Assumption}

Examining trade data, one can easily notice that a country can simultaneously import and export the same good. This observation, known as cross-hauling, is however inconsistent with the HO trade theory under perfect competition which assumes that products are homogenous across countries. This problem was first solved by Armington (1969), and is named the Armington assumption. The Armington assumption basically assumes that goods are not homogenous between countries, but are imperfect substitutes for each other. In simple words, this means that one should treat similar products produced in different countries as if they are different goods.

Therefore, studies by Shoven and Whalley (1984, p.1017) and Kehoe and Kehoe (1994) argue that a typical specification of many CGE trade models is to distinguish goods by industry and by country of origin. Thus, for example, an American-produced automobile is a different good from a Japanese-produced automobile-a close but imperfect substitute. According to Petersen (1997, p.5), the homogenous case of no difference between American and Japanese cars in this example corresponds to an infinitely high Armington elasticity between the two cars.

Kehoe and Kehoe (1994) comment on the advantages of the Armington specification as it accounts for the large amount of cross-hauling present in the data, where a country both imports and exports goods of the same product category. In a model where goods are homogeneous, crosshauling cannot exist. Still another advantage of the Armington specification is that it allows the consumer to have differing degrees of substitution among domestic and imported goods and allows for changes in the relative prices of different imported goods. How much of domestic production or imports is purchased by consumers depends on the relative prices and the Armington elasticity, which is a measure of the substitutability between domestic and imported products.

A final assumption regarding the treatment of trade in CGE models that is usually made is that countries are assumed to follow the small open economy assumption, which means that the country at hand is too small and cannot affect world prices. 


\subsection{Macroeconomic Closure}

The equations also include a set of constraints that have to be satisfied by the system as a whole, but are not necessarily considered by any individual agent. According to Lofgren, Harris, and Robinson (2002, p.13-15) the standard CGE model includes three macroeconomic balances: the (current) government balance, the external balance (the current account of the balance of payments, which includes the trade balance), and the Savings-Investment balance. A researcher can choose between different closure rules for these balances.

For the government balance, the closure could either be that government savings, which is the difference between current government revenues and current government expenditures, is a flexible residual while all tax rates are fixed. The other alternative is that the direct tax rates of domestic institutions (households and enterprises) are adjusted endogenously to generate a fixed level of government savings.

Regarding the external balance, which is the current account balance, the closure could be that that the real exchange rate is flexible while the current account balance (and trade balance) is fixed. If the current account surplus for example is below the exogenous level, a depreciation of the real exchange rate would correct this situation by simultaneously reducing spending on imports and increasing earnings from exports. Under the alternative external balance closure, the real exchange rate is fixed while current account (and the trade balance) is flexible.

Finally, for the Savings-Investment balance, closures could either be investment driven (the value of savings adjusts) or savings-driven (the value of investment adjusts). According to Lofgren, Harris, and Robinson (2002, p.1516), closure combining a fixed external balance, fixed real investment, and fixed real government consumption is usually preferable for CGE simulations that aim at estimating the equilibrium welfare changes of alternative policies.

\section{How Does a CGE Model Work}

In studying the possible impacts of a certain change in trade policy on the economy, once can use a static CGE model. The counterfactual experiment widely used in the CGE simulation, according to Kehoe and Kehoe (1994), is the empirical analogy of the comparative-static analysis used in theoretical work. This is shown in figure (2) in the appendix which summarizes the main steps involved in constructing and using CGE models.

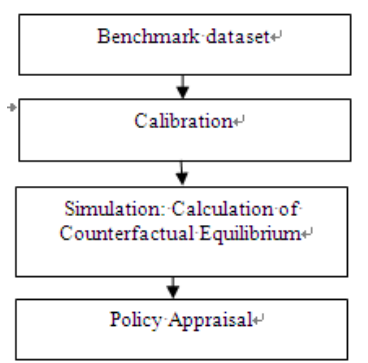

Figure 2. Flowchart of CGE Modeling.

Source: Based on Shoven and Whalley (1984, p.1019), and Bohringer, Rutherford, and Wiegard (2003, p.3).

The procedure as explained by Petersen $(1997, \mathrm{p} .4)$ is as follows: Begin the experiment with an assumption that the economy under study is in equilibrium in the presence of an existing policy regime and for the dataset in a chosen year. This dataset is considered the benchmark dataset. Using that data, parameter values are chosen so that the model will replicate this benchmark equilibrium through a model solution (called calibration). This "benchmark" or "observed" equilibrium dataset serves as the point of comparison for counterfactual-equilibrium analysis of any hypothetical policy change. The second step is to then simulate the policy change by altering the relevant policy parameters and calculating the new counterfactual equilibrium. This approach allows the researcher to predict what would have happened if the policy change had actually been made.

\subsection{Choosing Functional Forms}

Shoven and Whalley (1984, pp.1017-1018) argue that the selection of appropriate demand and production functions in CGE models requires that they be consistent with theory and at the same time be analytically tractable. The first constraint involves choosing functions that satisfy restrictions such as the Walras' Law for demand functions. The second requires that the demand and supply responses of the economy be reasonably easy to evaluate. This largely explains why most research done in this area often uses functional forms like Cobb- Douglas, Constant Elasticity of Substitution (CES), Linear Expenditure System (LES) among others.

The choice of a specific functional form, according to Shoven and Whalley (1984, p.1018) typically depends on how the researcher will use elasticities in the model. This point is best illustrated by considering the demand side of these models. For example, demands derived from CobbDouglas utility functions $(x i=\alpha i \mathrm{~m} / \mathrm{pi})$ are easy to work with, but have the restrictions of unitary income elasticity $(\eta \mathrm{m}=1)$, unitary uncompensated own-price elasticities ( $\eta \mathrm{i}$ $=1$ ), and zero cross-price elasticities. These restrictions are generally implausible, given empirical estimates of such elasticities estimated in the literature. That's why CGE models usually make use of more general functional forms like CES functions. Obviously, the normal approach is to select the functional form that best allows key parameter values like income and price elasticities to be accurately incorporated while allowing for tractability.

\subsection{Choosing Behavioral Elasticities}

After all information about the expenditures and revenues and the interactions of all agents have been included into a SAM, the modeler needs to provide the value of the exogenous parameters (called behavioral parameters) that characterize the behavior of producers and consumers. Ac- 
cording to Piermartini and Teh (2005, p.19), there are at least three types of behavioral parameters which are needed. First are the elasticities of substitution in value added which govern the substitutability of the primary factors of production. Second, are the Armington elasticities which determine the substitutability of the domestic vs. the imported products. Third, are the demand and income elasticities of the households.

\subsection{Calibration}

Calibration, as mentioned earlier, is the process of selecting the parameter values. As presented in figure (2), the economy is assumed to be in equilibrium, the so-called "benchmark" equilibrium. The next step is to choose the parameters of the model such that the model can reproduce this data set as an equilibrium solution. According to Shoven and Whalley (1984, p.1018), if CES or LES functions are to be used in the model, then exogenously specified elasticity values, which are usually based on previous literature estimates, are required in this procedure because the benchmark data only give price and quantity observations associated with a single equilibrium. On the demand side, for instance, only the slope of the budget constraints at the equilibrium consumption quantities is given by the benchmark data. The parameter values thus generated can then be used to solve for the alternative equilibrium associated with any changed policy regime. These are usually termed counterfactual equilibria.

Bohringer, Rutherford, and Wiegard (2003, p.5) argue that the researcher should conduct a consistency check that must necessarily hold before proceeding with policy analysis and that is the replication of the initial benchmark. In other words, the calibrated model must be capable of generating the base-year (benchmark) equilibrium.

\subsection{Counterfactual Equilibrium}

As presented in figure (2), once the calibration procedure is completed, a fully specified numerical model will be available and can now be used for studying the impacts of different policy changes. Therefore, one can start doing counterfactual experiments. This is basically asking the question what would happen to the equilibrium if...?, and thus the name counterfactual experiments. As indicated in Figure (2), following a policy change, a counterfactual equilibrium is computed for the new policy regime, and policy appraisal can be made by comparing the counterfactual to the benchmark equilibrium.

In the case of trade effects, one could ask the questions what would happen if the country at hand changes its trade policy. For example, what would happen if the country engages in unilateral trade liberalization, enters a new customs union, or reduces tariffs under a multilateral tariff reduction scheme.

\subsection{Measuring Welfare in CGE Models}

After calculating the counterfactual equilibrium, one can use comparative statics to compare welfare both before and after a trade policy change to arrive at policy conclusions. Different welfare measures have been proposed, but the most commonly used according to Shoven and Whalley (1984, p.1021) are Equivalent variation (EV) and Compensating variation $(\mathrm{CV})$.

Equivalent Variation uses current prices as the base, and asks what income change at the current prices would be equivalent to the proposed change in terms of its impact on utility. In other words, EV shows how much additional money is needed at the original prices to make the consumer as well off as he would be facing the new prices. In terms of a tariff removal, Piermartini and Teh (2005, p.14) explain EV as the amount of income, measured in current prices, that consumers would be willing to forego and still have the same level of well-being as before the tariff was removed.

Compensating Variation, on the other hand, uses new prices as the base, and asks what income change would be necessary to compensate the consumer for the price change. In other words, CV shows how much money should be given to the consumer to leave him as well off as he was facing the old prices.

Another possible measure of interest to policy makers is distributional effects of a policy change. One can look at differences between benchmark and counterfactual equilibria to evaluate income distribution effects; whether labor gains against property owners. Shoven and Whalley (1984, p.1022) argue that distributional effects from CGE models can be examined using the Lorenz curve, or the Gini coefficient. They further argue that one can examine changes in relative prices, changes in the use of factors of production across industries. Also, specifically for international trade models, one can examine changes in the country's terms of trade.

\section{Review of Results of CGE Trade Models in the Case of Egypt}

This section aims at reviewing the results of a number of papers studying the impact of different trade liberalization scenarios on the Egyptian economy using the CGE model.

\subsection{Egypt-EU Agreement}

A study by Konan and Maskus (1996) assessed the potential implications of different forms of trade liberalization between Egypt and the EU. The CGE approach employed treats Egypt as a small open economy in which production and household decisions follow standard neoclassical optimization assumptions. According to Konan and Maskus (1996, p.7), data used consists of a SAM, elasticities of substitution and transformation, export and import flow shares by region, tax and tariff rates. 1994 is considered the benchmark year in this paper. This study concluded that an association agreement with the EU has limited welfare gains to Egypt. Welfare gains reported are around $0.2 \%$ to 
$0.3 \%$ of GDP in real terms. Regarding income distribution issues, the paper found that the real wages of nonproduction labor is expected to experience a greater rise than the wages of production labor. This is attributed to the fact that Egypt is relatively well endowed with nonproduction labor.

Another paper by Konan and Maskus (2000, p.17) studied the counterfactual implications of different trade liberalization scenarios between Egypt and the EU using a CGE model. Specifically, the paper studied the welfare implications of two scenarios. The first scenario labeled EU_AT is a PTA with the EU in which Egypt eliminates all tariffs on EU imports, while the EU provides improved access in agricultural goods and textiles and clothing, resulting in an eight-percent rise in those Egyptian export prices to the EU. In this case, welfare as measured by the percentage change in real benchmark 1994 GDP measured in equivalent variation increases by $0.14 \%$. The second scenario, labeled EU_TOT extends scenario EU_AT. In this scenario, Egypt eliminates all tariffs on EU imports, while the EU provides more liberal access to domestic markets, resulting in a one-percent increase in all export prices to the EU, with an eight percent price increase in agriculture and textiles. Welfare gains in this case are as $0.27 \%$ using the same definition of welfare as in the first scenario.

A study by Hoekman and Konan (1998) measures the welfare gains that could accrue to Egypt if it was to pursue a trade association agreement with the EU. What's new in this paper is that the authors consider shallow vs. deep integration efforts between Egypt and the EU. According to Hoekman and Konan (1998, p.1) shallow integration is merely reducing tariff rates between the two sides. Deep integration, on the other hand, is defined as explicit actions by governments to reduce the market segmenting effect of domestic (nonborder) regulatory policies. Examples include health and safety regulations, competition laws, licensing and certification regimes, prudential requirements, environmental norms, and administrative procedures such as customs clearance practices. In other words, deep integration refers to not just the reduction of tariff barriers but also the reduction of nontariff barriers (NTBs) to trade. Results, according to Hoekman and Konan (1998, p.24) argue that given Egypt's highly diversified trading patterns, a shallow PTA with the EU will in fact lead to a small welfare decline. This reflects the fact that Egypt already has duty-free access to the EU for manufactures, implying that the loss in tariff revenues that will be incurred outweighs any possible trade creation that may result. The study therefore concludes that large welfare gains from an EgyptEU FTA are conditional upon the elimination of regulatory barriers and red tape. If deep integration efforts are pursued, the welfare gains may be substantial, from 4 percent to upwards of 20 percent growth in real GNP. The variance in these impact results indicates that it is important to have a good sense of how large the regulatory costs are.

\subsection{Unilateral Trade Liberalization}

Konan and Maskus (1996, p.18) in their Egypt CGE trade model conclude that the broader the trade liberalization adopted by Egypt, the bigger the expected welfare gains. The paper reported that at the extreme of full trade liberalization (zero percent tariffs on all imports from all trading partners), Egyptian GDP could increase by three percent. This was done using an input/output table for Egypt for the year 1989/1990.

Another paper by Konan and Maskus (2000, p.9) used the same procedure as in the previously mentioned paper, but using an updated IO table for Egypt for the year 1994. The results reported that full unilateral trade liberalization from Egypt's side could generate estimated welfare gains (measured as Hicksian equivalent variation) of 0.81 percent over benchmark 1994 levels. Other results show that the real exchange rate depreciates by 1.24 percent in order to maintain the benchmark current-account deficit.

Maskus and Konan (1997, pp.286-287) also reported similar results. A number of different trade liberalization scenarios were investigated, and the one with full unilateral trade liberalization generated the highest welfare gains. Specifically, this study concluded that NTB reform and full unilateral trade liberalization could raise Egyptian wellbeing by nearly $2.5 \%$ of GDP.

\subsection{Arab Economic Integration}

Konan (2003) modeled trade liberalization in Egypt in the context of Arab economic integration. The paper uses a CGE model for Egypt and reports that the change in welfare gains to Egypt from reducing trade barriers within the context of the Greater Arab Free Trade Area (GAFTA) are around $0.18 \%$ of GDP in the case of shallow integration, while welfare changes approach $2.74 \%$ in the case of deep integration. Again, deep integration refers to the identification and removal of non-tariff barriers (NTBs), which include import quotas, licensing and certification requirements, product standards, antidumping measures, customs procedures, and other regulatory and administrative barriers.

\subsection{Services Liberalization}

The study by Konan (2003) mentioned above argued that deep integration between Egypt and its Arab trade partners in the context of the GAFTA will yield significantly higher welfare gains than shallow integration. The paper takes another step and considers the effects of services trade liberalization in the same context. The change in GDP as reported by the paper exceeds $8 \%$ in the case of full services liberalization, as compared to a mere $2.05 \%$ in the case of shallow integration (reductions in tariffs on goods only).

On the same note, Konan and Kim (2004, p.1439) analyzed services trade liberalization in the case of Egypt using a trade CGE model. The paper uses a 1997 Egypt SAM which consists of 32 sectors: three agricultural, petroleum, mining, 20 manufacturing, and seven services sectors. The paper considered three types of services liberalization. First, is Border Services Liberalization which involves the re- 
moval of cross-border barriers in services trade. Second, is Investment Services Liberalization which involves the elimination of internal barriers to foreign investment in services sectors. Third, is Joint Services Liberalization which considers the combined effects of border and investment liberalization. Results from Konan and Kim (2004, p.1444) report that the elimination of border barriers improves household welfare by 0.78 per cent and real output by 1.07 per cent. Investment liberalization, on the other hand, leads to welfare gains of 6.90 per cent and real output gains of 11.85 per cent. Thus, the overall gains from services liberalization are primarily due to foreign investment in the services sector. Taken jointly, border and investment liberalization improves real output by 12.9 per cent in the case of Egypt.

\subsection{Egypt-USA FTA}

Hoekman, Konan and Maskus (1998) employed the same CGE setup used in studies mentioned above to evaluate potential welfare impacts of Egyptian trade liberalization within the context of the EU association agreement, only this time the paper studies the potential effects due to a possible Egypt-US FTA. Two scenarios are investigated. A shallow integration scenario, and a deep integration scenario which, as before, involves not only reduction of tariffs on goods, but also the removal of NTBs. Results from Hoekman, Konan and Maskus (1998, p.30-32) indicate that welfare changes account to $1.26 \%$ in the case of a shallow agreement, and $1.84 \%$ in the case of deep integration type of agreement.

Another study by Hoekman and Konan (2005) also used a static competitive CGE analysis to study the possible impacts of an Egypt-USA free trade agreement. The study uses the same framework as before, but this time it investigates the shallow and deep integration effects of Egypt going into a FTA with the USA as well as with the EU and GAFTA countries. Results from Hoekman and Konan (2005, p.54) report changes in real GDP of $1.79 \%$ in the case of a shallow agreement, and $2.82 \%$ in the case of deep integration agreement.

A rather interesting result appears in the case of shallow integration in the study by Hoekman and Konan (2005, p.54) which is in line with the Stopler-Samuelson theorem of trade. We know that the Stopler-Samuelson theory of trade asserts that an increase in the price of a good raises the real return of the factor intensive in the production of that good, and reduces the real return of the other factor. So, if we think of Egypt as a country that is relatively more labor intensive in its production, then we would expect free trade to raise the price of labor intensive products, which should in turn lead to raising the labor return in comparison to capital return. Specifically in this case, the return to capital has decreased by $0.42 \%$, while the return to labor has increased by $1.99 \%$.

\section{Conclusion}

This paper provides a survey of the recent literature on CGE models used to analyze the welfare effects of trade policy changes. Special reference is provided for the case of Egypt. In conclusion to all the studies considering the welfare and distributional effects of different Egyptian trade liberalization scenarios using the CGE model, one can notice that different papers studying different trade liberalization scenarios between Egypt and different trade partners all agree that there is some potential for welfare gains.

Although the exact measures of welfare differ from one paper to the other, one can reach a common conclusion. This conclusion is that regardless of the scenario being studied, welfare gains are always expected to be higher when the trade policy change is accompanied by improvements in other complementary policies and procedures. Konan and Maskus (2000), for example, conclude that trade liberalization in the face of distortionary taxes, is liable to produce markedly smaller welfare gains than is available from joint policy reform that includes trade liberalization as well as tax policy reform. Likewise, Hoekman and Konan (1998, p.24) concluded that deep integration between Egypt and the EU is more likely to produce welfare gains than shallow integration. The same point is reported in Konan (2003) which concludes that the rewards of deep integration are significantly higher than those of traditional shallow integration in the case of trade liberalization between Egypt and other Arab countries.

\section{References}

[1] Armington, Paul S. 1969. A theory of demand for products distinguished by place of production. International Monetary Fund Staff Papers 16 (March): pp. 159-78.

[2] Arrow, K.J. and Debreu, G. 1954. Existence of an equilibrium for a competitive economy. Econometrica 22, (July), pp.: 265-290.

[3] Bohringer, Christoph, Thomas Rutherford, and Wolfgang Wiegard. 2003. Computable general equilibrium analysis: Opening a black box. Discussion Paper no.03-56. Center for European Economic Research.

[4] Borges, Antonio. 1986. Applied general equilibrium models: An assessment of their usefulness for policy analysis. OECD Economic Studies 7, pp.: 7-43.

[5] Bouet, Antoine. 2008. The expected benefits of trade liberalization for world income and development: Opening the black box of global trade modeling. IFPRI Food Policy Review 8. International Food Policy Research Institute, Washington, D.C.

[6] Deardorff, Alan V. and Robert M. Stern. 1986. The Michigan model of world production and trade: Theory and applications. Cambridge: MIT Press.

[7] Dervis, K., J. De Melo and Sherman Robinson. 1982. General equilibrium models for development policy. Washington, D. C.: The World Bank.

[8] El-Agraa, Ali. 1989. The theory and measurement of inter- 
national economic integration, The Macmilan Press Ltd., Hong Kong.

[9] Francois Joseph F. and Kenneth A. Reinert. 1997. Applied methods for trade policy analysis - A handbook. Cambridge University Press, United Kingdom.

[10] Hansen, T. and H. Scarf. 1973. The computation of economic equilibria. Cowles Foundation Monograph No. 24, New Haven: Yale University Press.

[11] Helmy, Omneia. 2005. The impact of trade liberalization on government revenues in Egypt. ECES Working Paper no.101. Cairo, Egypt: Egyptian Center for Economic Studies.

[12] Hertel, Thomas. 1997. Global trade analysis: Modeling and applications. Cambridge: Cambridge University Press.

[13] Hoekman, Bernard, Denise Eby Konan, and Keith Maskus. 1998. An Egypt-US free trade agreement: Economic incentives and effects. World Bank Working Paper no.98-02.

[14] Hoekman, Bernard, and Denise Eby Konan. 1998. Deep integration, nondiscrimination, and Euro-Mediterranean free trade. Paper Presented at the conference Regionalism in Europe: bGeometries and Strategies After 2000, Bonn November 6-8, 1998.

[15] Hoekman, Bernard and Denise Eby Konan. 2005. Economic Implications of an Egypt - US FTA. in Robert Lawrence and Ahmed Galal, Anchoring Reform with a US-Egypt Free Trade Agreement, Washington: Institute for International Economics Press.

[16] Johansen, L. 1960. A multi-sectoral study of economic growth. Amsterdam: North-Holland.

[17] Kehoe, Patrick, and Timothy Kehoe. 1994. A primer on static applied general equilibrium models. Federal Reserve Bank of Minneapolis Quarterly Review 18 (1).

[18] Konan, Denise Eby and Keith E. Maskus. 1996. A computable general equilibrium analysis of Egyptian trade liberalization scenarios. Working Paper no.97-01.

[19] Konan, Denise Eby and Keith E. Maskus. 1997. A computable general equilibrium analysis of Egyptian trade liberalization scenarios. in: Regional Partners, Global Markets: Limits and Possibilities of the Euro-Mediterranean Agreements. Ahmed Galal and Bernard Hoekman (eds.). London, Center for Economic Policy Research in Europe (CEPR) and Brookings Institute.

[20] Konan, Denise Eby and Keith E. Maskus. 2000. Bilateral trade patterns and welfare: An Egypt-EU preferential trade agreement. Working Paper no.00-1.

[21] Konan, Denise Eby and Keith E. Maskus. 2000. Joint trade liberalization and tax reform in a small open economy: The case of Egypt. Journal of Development Economics 61 (2), pp.:365-392.

[22] Konan, Denise Eby, and Karl E. Kim. 2004. Beyond border barriers: The liberalization of services trade in Egypt and Tunisia. The World Economy 27 (9): pp.1429-1447.

[23] Konan, Denise Eby. 2003. Alternative paths to prosperity: Trade liberalization in Egypt and Tunisia. in Ahmed Galal and Bernard Hoekman, editors, Arab Economic Integration: Between Hope and Reality, Brookings Institute.

[24] Leontief, W. 1941. The structure of the American economy, 1919-1939. Oxford: Oxford University Press.

[25] Lofgren, Hans, Rebecca Lee Harris, and Sherman Robinson. 2002. A standard computable general equilibrium model in GAMS. IFPRI Microcomputer sin Policy Research no.5. Washington, D.C.: International Food Policy Research Institute.

[26] Maskus, Keith E., and Denise Eby konan. 1997. Trade liberalization in Egypt. Review of Development Economics 1 (3), pp.: 275-293.

[27] Parlow, Anton. 2009. Does trade promote peace? A new window in economics. Department of Economics, University of Wisconsin-Milwaukee.

[28] Petersen, T. Ward. 1997. An introduction to CGE-Modeling and an illustrative application to Eastern European Integration with the EU. Institute of Economics, University of Copenhagen.

[29] Piermartini, Roberta and Robert Teh. 2005. Demystifying modeling methods for trade policy. WTO Discussion Paperno.10. Geneva: World Trade Organization.

[30] Schiff, Maurice, and L. Alan Winters. 2003. Regional integration as politics. Chapter 7 in Regional Integration and Development, edited by Maurice Schiff and Alan Winters. Oxford University Press and the World Bank.

[31] Shoven, J. and J. Whalley. 1984. Applied general equilibrium models for taxation and international trade: An introduction and survey. Journal of Economic Literature 22 (3): pp.1007-1052.

[32] Smith, A. 1776. An inquiry into the nature and causes of the wealth of nations. London: W. Strahan \& T. Cadell.

[33] Wing, Ian Sue. 2004. Computable general equilibrium models and their use in economy wide policy analysis. Technical note no.6. MIT Joint Program on the Science and Policy of Global Change.

[34] World Bank. 2000. Trade blocs. World Bank Policy Research Report. New York: Oxford University Press. 